\title{
THE ANTIBACTERIAL ACTIVITY OF AQUEOUS AND ALCOHOLIC EXTRACTS OF SALVADORA PERSICA ON SEVEN TYPES OF ORAL BACTERIAL STRAINS
}

\author{
Muna BadeE'A Abdulaziz, Aya Shamal Al-MUfFti and Shivan Othman Hayder \\ Dept. of Pharmacy, Duhok Technical Institute, Duhok Polytechnic University,Kurdistan Region- Iraq
}

(Received: October 5, 2020; Accepted for Publication: December 6, 2020 )

\begin{abstract}
Salvadora persica, commonly known as the toothbrush tree (Miswak), is an evergreen shrub with fibrous branches . Different parts of the tree stems, roots, twigs have been used as natural antimicrobial sources for the maintenance of oral hygiene. It has been found that $S$. persica has analgesic, antiplaque, anticariogenic and antifungal properties. The aim of this study was to observe the antibacterial action of the aqueous and alcoholic extracts of the stems of $S$. persica against seven types of oral bacteria. The stems of $S$. persica were obtained from a local market in Duhok governorate and the pathogens were collected from the laboratory of Azadi hospital and cultured on blood, nutrient and MacConkey agars. The extracts were prepared using Rotary Vacuum Evaporator, followed by the preparation of the stock solutions. Overall both the aqueous and alcoholic extracts exhibited antibacterial activity against all the types of the bacteria. However, the aqueous extract showed stronger antibacterial action against all strains in particular gram positive bacteria. Methanol and isopropanol were effective against gram negative bacteria. $S$. persica has proved its efficacy as a natural antimicrobial plant for cleansing the oral cavity and can be used as alternative to other expensive medicinal products.
\end{abstract}

KEYWORDS: Salvadora persica, Chewing sticks, Antimicrobial, Miswak, Toothbrush ,Oral hygiene.

\section{INTRODUCTION}

$\mathbf{M}$ edicinal herbs have been used among different populations since antiquity to maintain a good general body and oral health. World Health Organization (WHO) stated that up to $80 \%$ of the communities of developing countries use the medicinal plants as remedies. The popularity of herbal medicine has been expanded throughout the world reaching Africa as these remedies are at hand and less expensive besides the drug shortage [18].

Many herbs have been used as antimicrobial agents for the treatment of oral diseases; such as caries and periodontitis with over than 180 plant species that are used a natural chewing sticks. The most common species are S. persica (Peelu), Azadirachta indica (Neem, widely distributed in Indian subcontinent).Acacia arabica (Kikar) and Olea europaea (Zaitoon) popular in SouthernEastern Africa. Glycosmis pentaphylla, common in India, Malaysia, Southern China and Philippine, Capparis aphylla (Khiran, grows in dry regions of Pakistan) [3,10,20,23]. One of these plants that are used as a natural toothbrush is the $S$. persica that belongs to family Salvadoraceae, commonly called Miswak or Siwak in Muslim communities. It is widespread in arid regions of India, Africa, the Middle East and the Arabian Peninsula and often grows on saline lands [16]. It is an evergreen small tree, 4$6 \mathrm{~m}$ tall and usually $1 \mathrm{ft}$ in diameter. The smooth green leaves are edible and used traditionally for the treatment of coughs, asthma, rheumatism, piles, scurvy, etc. The stems, twigs, and roots have been used for centuries by the Arabs for having healthy, white and bright teeth $[2,16]$. They are soft and can be easily smashed by teeth after trimming and shaping them to resemble toothbrushes [8].

The investigations of the phytochemical constituents of $S$. persica revealed the presence of alkaloids, flavonoids, tannins, saponins, sulphur, glycosides, steroids, resins, carbohydrates, vitamin $\mathrm{C}$, calcium and volatile oils besides oleic and linoleic acids, sodium chloride, potassium chloride and salvadourea which are responsible for bioactivity of Miswak [2,13].

Previous studies screened different solvent extracts (alcoholic and aqueous) for the presence of these constituents. It was shown that all phytochemicals were absent in hexane extracts of stems and twigs while only alkaloids were found in Chloroform extract. However all of the phytochemicals were present in the ethanol extract of the twigs and the aqueous extract of the stem [12]. In addition, Darout et al. proved 
the presence of sulphate, thiocyanate, chloride, and nitrate in the aqueous extract of roots and stems [11].Other studies revealed the presence of benzylamides, phosphorus, calcium, fluoride and silica $[15,19]$. The polarity of the solvents could be the reason for this variation in the presence of these constituents. In contrast other studies demonstrated different results. In general the strong antibacterial and antifungal activity of S.persica have been confirmed by previous studies, however, the contradiction in the results could be due to the used techniques for the extraction, tested concentration, type of solvent extracts, the used part of S.persica and its origin or geographical distribution [9].

The present study was performed to observe the antimicrobial activity of aqueous and alcoholic extracts of Miswak against seven types of gram-positive and gram-negative oral bacterial strains that cause periodontitis and dental caries.

\section{MATERIALS AND METHOD -collection of bacterial specimens:}

Pathogenic bacteria (Staphylococcus aureus, Streptococcus pneumonia, Streptococcus agalactiae, Enterococcus faecalis, Escherichia coli, Klebsiella pneumonia, Pseudomonas aeruginosa) were obtained from the laboratory of Azadi hospital and cultured on blood, nutrient and MacConkey agars. The study was carried out in the microbiology laboratory of Duhok Technical Institute, Duhok Polytechnic University.

\section{-Collection of Miswak and preparation of aqueous and alcoholic extracts}

The stems of Miswak were collected from a local market in Duhok governorate, Kurdistan region of Iraq. The stems were kept at room temperature for a week to dry thoroughly. An electric grinder was used to grind the Miswak into a power. Approximately 50gm of Miswak powder was soaked into $500 \mathrm{ml}$ of distilled water and left in it for two days. Similarly, 50gm of Miswak was added to $500 \mathrm{ml}$ of methanol and $500 \mathrm{ml}$ of isopropanol and left for 3 days. Each solution was filtered using filter paper (Whatman No.1). Concentrated solutions were obtained using Rotary Vacuum Evaporator, 60c and 40c for distilled water and alcohol solutions respectively. Then the solutions were preserved in refrigerator for later use. The stock solution was prepared by adding $0.2 \mathrm{gm}$ of crude extract to a flask containing $200 \mathrm{ml}$ of distilled water, likewise, $200 \mathrm{ml}$ of each of the solvents (methanol and isopropanol) were mixed with 0.2 gm of crude extract. Finally, these stock solutions were used for preparing five different concentration $(200,400,600,800,1000) \mathrm{mg} / \mathrm{ml}$.

\section{-Agar diffusion method:}

The antimicrobial sensitivity test was performed on Muller Hinton agar plates using agar diffusion method by spreading bacteria suspension smoothly on the agar plates. The required number of holes on agar were made using sterile glass capillary which then filled with sterile extract (aqueous or alcohol) made from $S$. persica stock solution. The plates were left for a period of time for proper diffusion of plant extract into the media then incubated at $37^{\circ} \mathrm{C}$ for $24 \mathrm{hrs}$. The mean diameter of inhibition zone was measured in ( $\mathrm{mm}$ ) excluding the well's diameter.

\section{RESULTS}

In the present study, all the different concentrations of aqueous, methanol and isopropanol extracts of $S$. persica showed activity against all the seven types of the oral bacteria (Table 1). The aqueous extract had a higher inhibitory action than the alcoholic extracts. The concentration of $1000 \mathrm{mg} / \mathrm{ml}$ of the three extracts was the most effective one on the strains. The figures below represent the results of the antibacterial activity of the three extracts through the measurement of the inhibition zones in $(\mathrm{mm})$. The negative control (distilled water) had zero effect on the tested pathogens.

The aqueous extract showed a stronger activity against Gram-positive bacteria (range 3.7- $6.4 \mathrm{~mm}$ ) than Gram-Negative bacteria (range $3.4-4.4 \mathrm{~mm}$ ). Strept. pneumoniae was the most sensitive one to the aqueous extract among all the strains; with inhibition zone of 4 $\mathrm{mm}$ at concentration $200 \mathrm{mg} / \mathrm{ml}$ and maximum zone of inhibition $(9 \mathrm{~mm})$ was recorded at 1000 $\mathrm{mg} / \mathrm{ml}$ (Figure 1) . However, the lowest effect was noticed on $P$. aeruginosa with inhibition zone of $(2 \mathrm{~mm}, 6 \mathrm{~mm})$ at concentration 200 $\mathrm{mg} / \mathrm{ml}$ and $1000 \mathrm{mg} / \mathrm{ml}$ respectively. Overall, both alcoholic extracts of $S$. persica exhibited a relative effect in contrast to the aqueous extract. Methanol and isopropanol extracts had an observable effect on Gram-negative bacteria more than Gram-positive bacteria. Methanol had high antibacterial activity against $K$. pneumonia $(8.4 \mathrm{~mm}$ at concentration $1000 \mathrm{mg} / \mathrm{ml})$ and $P$. aeruginosa (8 at $1000 \mathrm{mg} / \mathrm{ml}$ ) (Figure 2). The weakest growth inhibition was observed in $E$. 
faecalis $(5.3 \mathrm{~mm}$ at $1000 \mathrm{mg} / \mathrm{ml})$. Among Grampositive bacteria, Strept. pneumoniae $(6 \mathrm{~mm}$ at $1000 \mathrm{mg} / \mathrm{ml})$ and $S$. aureus $(7.2 \mathrm{~mm}$ at 1000 $\mathrm{mg} / \mathrm{ml}$ ) showed the highest sensitivity to methanol extract.

Similarly, isopropanol showed high antibacterial activity against $K$. pneumonia $(9.2$ at concentration $1000 \mathrm{mg} / \mathrm{ml}$ ) and $P$. aeruginosa $(7.6 \mathrm{~mm}$ at $1000 \mathrm{mg} / \mathrm{ml})$, followed by the grampositive bacteria Strept. pneumoniae, S. aureus and E.coli with inhibition zones $(7 \mathrm{~mm}, 6.3 \mathrm{~mm}$ and $6 \mathrm{~mm}$ at $1000 \mathrm{mg} / \mathrm{ml}$ ) respectively.

\section{-Statistical Analysis}

The Analysis of variance (ANOVA) showed no clear difference among the means of the three extracts depending on the obtained significance level (0.434) which was greater than (0.05) (Table 2) . Post Hoc - Multi Comparisons also confirmed the result where the significance level was higher than $(0.05)$ according to (LSD) and (Duncan) methods (Table 3 and Table 4) .

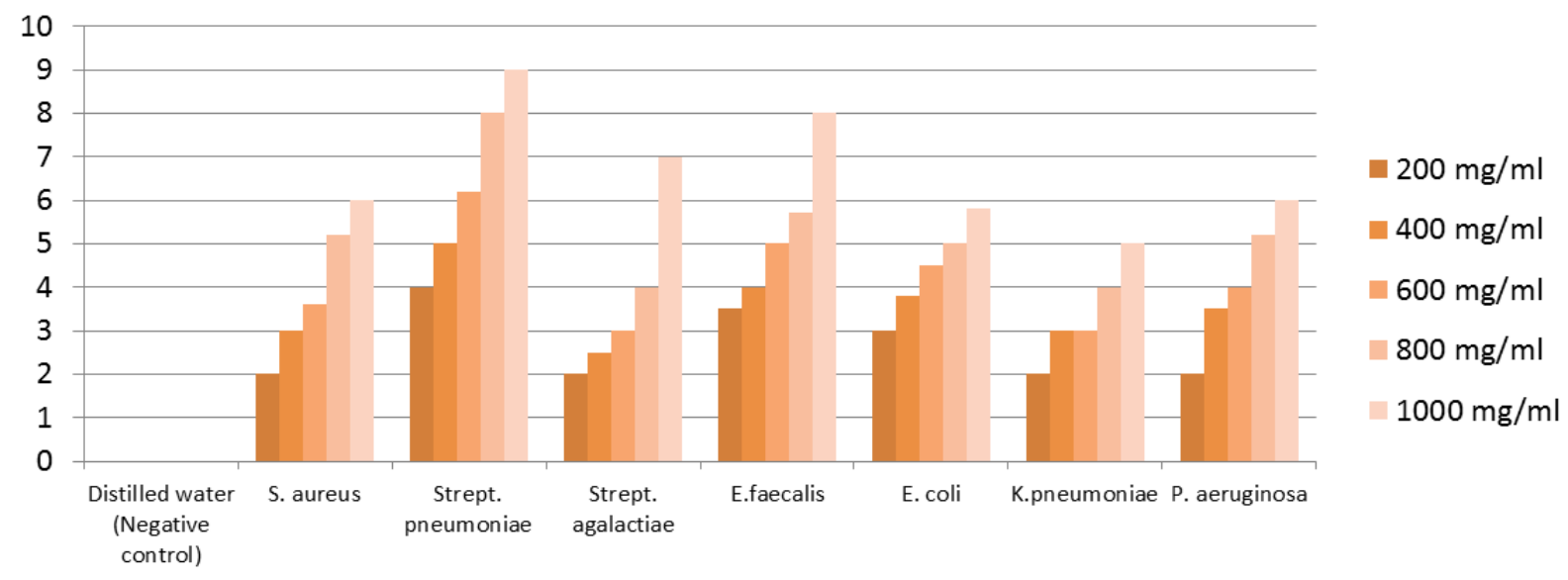

Fig. (1):The effects of aqueous extract of $S$. persica on the growth of bacterial isolates.

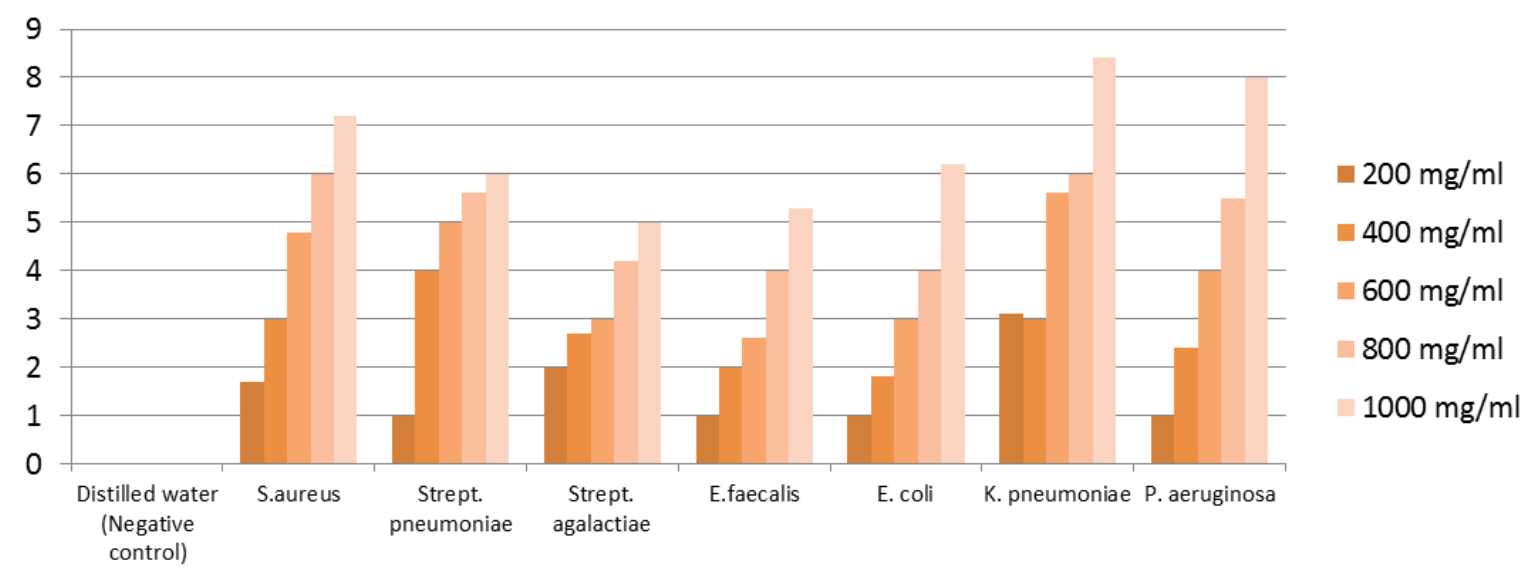

Fig. (2): The effects of methanol extract of S. persica on the growth of bacterial isolates. 


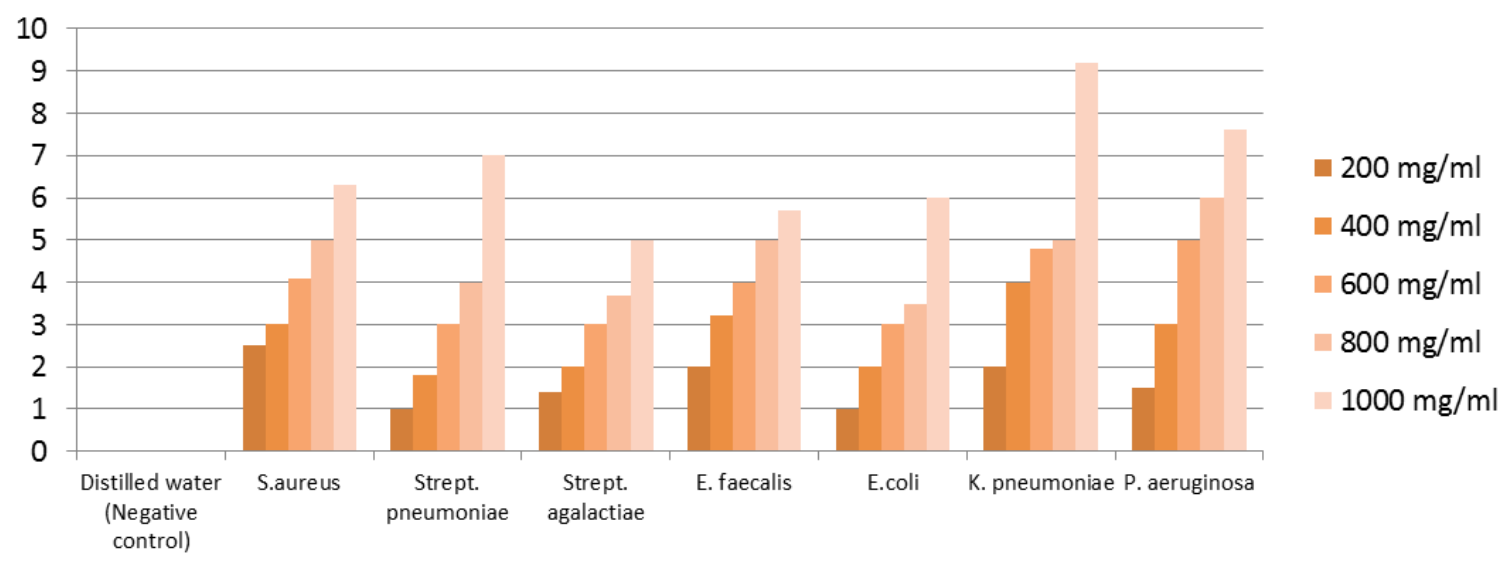

Fig. (3):The effects of isopropanol extract of S. persica on the growth of bacterial isolates.

Table (1): Mean and standard deviation values of zone of inhibition $(\mathrm{mm})$ of all bacteria treated with aqueous, methanol and isopropanol extracts of S. persica .

\begin{tabular}{lccc}
\hline \multicolumn{1}{c}{ Types of bacteria } & \multicolumn{1}{c}{ Mean \pm SD } & Isopropanol extract \\
\hline Staphylococcus aureus & Aqueous extract & Methanol extract & $4.18 \pm 1.53$ \\
\hline Streptococcus pneumonia & $3.96 \pm 1.62$ & $4.54 \pm 2.21$ & $3.36 \pm 2.33$ \\
\hline Streptococcus agalactiae & $6.44 \pm 2.06$ & $4.32 \pm 2.00$ & $3.02 \pm 1.41$ \\
\hline Enterococcus faecalis & $3.7 \pm 1.98$ & $3.38 \pm 1.20$ & $3.98 \pm 1.46$ \\
\hline Escherichia coli & $5.24 \pm 1.76$ & $2.98 \pm 1.69$ & $3.1 \pm 1.88$ \\
\hline Klebsiella pneumonia & $4.42 \pm 1.07$ & $3.2 \pm 2.02$ & $5 \pm 2.63$ \\
\hline Pseudomonas aeruginosa & $3.4 \pm 1.14$ & $5.22 \pm 2.25$ & $4.62 \pm 2.41$ \\
\hline
\end{tabular}

Table (2): Analysis of variance (ANOVA) of the three extracts.

\begin{tabular}{cccccc}
\hline Sample & Sum of Squares & Df & Mean Square & F & Sig. \\
\hline Between Groups & 1.369 & 2 & .684 & .875 & .434 \\
\hline Within Groups & 14.077 & 18 & .782 & & \\
\hline Total & 15.446 & 20 & & & \\
\hline
\end{tabular}

\section{Table (3): Post Hoc Tests}

\begin{tabular}{|c|c|c|c|c|c|c|}
\hline \multicolumn{7}{|c|}{ Multiple Comparisons / Dependent Variable: Sample } \\
\hline \multicolumn{7}{|c|}{ LSD } \\
\hline \multirow[t]{2}{*}{ (I) factor } & \multirow[t]{2}{*}{ (J) factor } & \multirow{2}{*}{$\begin{array}{l}\text { Mean Difference } \\
(I-J)\end{array}$} & \multirow[t]{2}{*}{ Std. Error } & \multirow[t]{2}{*}{ Sig. } & \multicolumn{2}{|c|}{ 95\% Confidence Interval } \\
\hline & & & & & Lower Bound & Upper Bound \\
\hline \multirow[t]{2}{*}{1.00} & 2.00 & .49714 & 47270 & .307 & -.4960 & 1.4902 \\
\hline & 3.00 & .57714 & .47270 & .238 & -.4160 & 1.5702 \\
\hline \multirow[t]{2}{*}{2.00} & 1.00 & -.49714 & .47270 & .307 & -1.4902 & .4960 \\
\hline & 3.00 & .08000 & .47270 & .867 & -.9131 & 1.0731 \\
\hline \multirow[t]{2}{*}{3.00} & 1.00 & -.57714 & .47270 & .238 & -1.5702 & .4160 \\
\hline & 2.00 & -.08000 & .47270 & .867 & -1.0731 & .9131 \\
\hline
\end{tabular}


Table (4): Duncan ${ }^{\mathrm{a}}$ test

\begin{tabular}{ccc}
\hline factor & $\mathrm{N}$ & \multicolumn{1}{c}{ Subset for alpha $=0.05$} \\
\cline { 3 - 3 } & & 3.8943 \\
\hline 3.00 & 7 & 3.9743 \\
\hline 2.00 & 7 & 4.4714 \\
\hline 1.00 & 7 & .263 \\
\hline Sig. & $\begin{array}{r}\text { Means for groups in homogeneous subsets are displayed. } \\
\text { a. Uses Harmonic Mean Sample Size }=7.000 .\end{array}$ \\
\hline &
\end{tabular}

\section{DISCUSSION}

S.Persica has been one of the significant plants that are used as an antimicrobial agent for oral hygiene in different countries. The extract of Miswak have proved efficacy against bacterial strains and other fungi $[14,19]$. In the present study, aqueous and alcoholic extracts of $S$. persica were used to demonstrate their antibacterial activity against seven types of oral bacterial isolates. This study showed that the inhibition zone increases with the increase of concentration of the extract; accordingly the concentration of $1000 \mathrm{mg} / \mathrm{ml}$ had the highest effect on all strains. The aqueous extract exhibited a stronger antibacterial activity on all types of bacteria than the methanol extracts and this was also observed in previous studies showing the efficiency of the aqueous extract $[5,22]$. On the contrary, Al-Ayed et al. and Siddeegh documented that the alcoholic extract had stronger antibacterial action than the aqueous extract $[4,21]$. The activity of both extracts on the same types of bacteria was also different where the aqueous extract had a clear effect on the Gram-positive strains. Conversely, both methanol and isopropanol exhibited a higher effectiveness on Gram-negative bacteria .The results showed that the aqueous extract had a significant activity against Strept. pneumoniae, E.faecalis followed by Strept. agalactiae and $S$. aureus. Our results are in agreement with previous studies where they reported the susceptibility of E. faecalis and Strept. pneumoniae to aqueous extract and the sensitivity of gram-positive bacteria to aqueous extract, especially the Streptococcus species [5, $6,17]$. In comparison to the alcoholic extracts, methanol and isopropanol had a significant effect on K.pneumoniae, $P$. aeruginosa and $E$. coli, where these bacteria had less inhibition zone when treated with the aqueous extract. The findings of Al-Ayed et al. support the results of the present study. They indicated that methanol was highly effective against these gram-negative bacteria [4]. However, their results disagree with Al-Bayati and Sulaiman where their results showed the resistance of $P$. aeruginosa to the all concentrations of the methanol extract [5].

The Significance tests indicated the absence of difference in the activity among the three extracts where the significance level (0.434) was higher than (0.05).

The degree of sensitivity of strains to the extracts indicates that each extract has different constitutes of $S$. persica and it may also depend on the $\mathrm{pH}$ of the extract .The aqueous extract has higher $\mathrm{pH}$ than the alcoholic extracts [17]. Abhary and Al-Hazmi stated that the constituents of Miswak increase the production of saliva and buffers its $\mathrm{pH}$ and as a consequence the number of bacteria was reduced significantly. The considerable amount of chlorides and minerals in the aqueous extract contribute to the reduction of the bacterial numbers. Additionally, the polarity of the solvent has a clear effect on the action of $S$. persica constituents. They documented that aqueous extract had more inhibitory effect on $L$. acidophilus (gram $+\mathrm{ve}$ ) and $P$. aeruginosa (gram -ve) than the alcoholic extracts, this was due to the high amount of chloride, while hexane had no effect at all on $P$. aeruginosa [1] .Our findings are in consonance with Abhary and AlHazmi study. The aqueous extract had a notable effect on $P$. aeruginosa. Almas et.al demonstrated that the antimicrobial activity of the chewing sticks differs according to type and origin of the plant. The aqueous extract of the Arak (S. persica) had some effect on Strept. faecalis at $50 \%$ concentration while Peelu (Salvadora persica from Pakistan) did not show 
any effect .However, they stated that their experiment took a month and the sticks were not fresh at the time of the test, hence they showed no activity [7].

\section{CONCLUSION}

The results showed antimicrobial activity of both aqueous and alcoholic extracts against all the bacterial strains and the aqueous had a stronger effect than methanol and isopropanol. The aqueous inhibited the gram-positive bacteria more than the gram-negative bacteria. There was no clear difference in the action of the alcoholic extracts where both had a greater effect on the growth of gram-negative bacteria. However, the overall inhibition zones where significantly low when compared to the previous studies .This could be due to the type of S. persica or its geographical distribution. Additional research is required for understanding the activity of each species of $S$. persica and the factors that influence their efficacy.

\section{REFERENCES}

Abhary, M., \& Al-Hazmi, A. (2016). Antibacterial activity of Miswak (Salvadora persicaL.) extracts on oral hygiene. Journal of Taibah University for Science, 10(4), 513-520. doi:10.1016/j.jtusci.2015.09.007

Ahmad, H., \& K, R. (2012). Biological Activities of Salvadora persica L. (Meswak). Medicinal \& Aromatic Plants, 02(04). doi:10.4172/21670412.1000129

Hooda, A., Rathee, M., \& Singh, J. (2009). Chewing Sticks In The Era Of Toothbrush: A Review. The Internet Journal of Family Practice, 9(2). doi: $10.5580 / 795$

Al-Ayed, M. S., Asaad, A. M., Qureshi, M. A., Attia, H. G., \& Almarrani, A. H. (2016). Antibacterial Activity of Salvadora persica L. (Miswak) Extracts against Multidrug Resistant Bacterial Clinical Isolates. Evidence-Based Complementary and Alternative Medicine, 2016, 1-5. doi:10.1155/2016/7083964

Al-Bayati, F.A., \& Sulaiman, K.D. (2008). In Vitro Antimicrobial Activity of Salvadora persica L. Extracts Against Some Isolated Oral
Pathogens in Iraq. Turkish Journal of Biology, 32, 57-62.

Almaghrabi, M. K. (2018). Antimicrobial activity of Salvadora persica on Streptococcus pneumoniae. Biomedical Research, 29(19). doi:10.4066/biomedicalresearch.29-18-1081

Almas K. (2001). The antimicrobial effects of seven different types of Asian chewing sticks. Odonto-stomatologie tropicale = Tropical dental journal, 24(96), 17-20

Almas, K., \& Al-Zeid, Z. (2004). The Immediate Antimicrobial Effect of a Toothbrush and Miswak on Cariogenic Bacteria: A Clinical Study. The Journal of Contemporary Dental Practice, 5(1), 105-114. doi:10.5005/jcdp-5-1105

Aumeeruddy, M. Z., Zengin, G., \& Mahomoodally, M. F. (2018). A review of the traditional and modern uses of Salvadora persica L. (Miswak): Toothbrush tree of Prophet Muhammad. Journal of Ethnopharmacology, 213, 409-444. doi:10.1016/j.jep.2017.11.030

Bulbul,I.\& Jahan, N.(2016). Study on antioxidant and antimicrobial activities of methanolic leaf extract of Glycosmis pentaphylla against various microbial strains. Journal of Pharmacognosy and Phytochemistry, 5(4), 53-57.

Darout, I.A., Christy, A., Skaug, N., \& Egeberg, P.K. (2000). Identification and quantification of some potentially antimicrobial anionic components in miswak extract. Indian Journal of Pharmacology, 32, 11-14.

Gupta, A., Verma, S., Kushwaha, P., Srivastava, S., \& S, R. A. (2015). Phytochemical and Antioxidant Studies of Salvadora persica L. Stem \& Twig. Indian Journal of Pharmaceutical Education and Research, 49(1), 71-75. doi:10.5530/ijper.49.1.10

Haque, M., \& Alsareii, S. (2015). A review of the therapeutic effects of using miswak (Salvadora Persica) on oral health. Saudi Medical Journal, 36(5), 530-543. doi:10.15537/smj.2015.5.10785

K, P., S, J. B., \& J, P. (2019). Identification Of Ethnomedicinal Compounds And 
Antimicrobial Studies Of Salvadora Persica

L. (Salvadoraceae). Asian Journal of Pharmaceutical and Clinical Research, 183188. doi:10.22159/ajpcr.2019.v12i4.31256

Khalil, A. T. (2006). Benzylamides from Salvadora persica. Archives of Pharmacal Research, 29(11), 952-956. doi:10.1007/bf02969277

Khatak, M., Khatak, S., Siddqui, A., Vasudeva, N., Aggarwal, A., \& Aggarwal, P. (2010). Salvadora persica. Pharmacognosy Reviews, 4(8), 209. doi:10.4103/0973-7847.70920

Omer, A., Qarani, S., \& Khalil, A. (2018). In vitro antimicrobial activity of Miswak extracts against some oral pathogenic isolates. Zanco Journal of Medical Sciences (Zanco J Med Sci), 14(1), 71 - 78.

Megersa, M., Jima, T. T., \& Goro, K. K. (2019). The Use of Medicinal Plants for the Treatment of Toothache in Ethiopia. Evidence-Based Complementary and Alternative Medicine, 2019, 1-16. doi:10.1155/2019/2645174

Mujeeb, M., Akhtar, J., Siddique, K., \& Bi, S. (2011). A review on phytochemical and pharmacological investigations of miswak (Salvadora persica Linn). Journal of
Pharmacy and Bioallied Sciences, 3(1), 113. doi:10.4103/0975-7406.76488

Niazi, F., Naseem, M., Khurshid, Z., Zafar, M. S., \& Almas, K. (2016). Role of Salvadora persica chewing stick (miswak): A natural toothbrush for holistic oral health. European Journal of Dentistry, 10(02), 301-308. doi:10.4103/1305-7456.178297

Siddeeqh, S. (2016). Estimation of Antimicrobial Properties of Aqueous and Alcoholic Extracts of Salvadora Persica (Miswak) on Oral Microbial Pathogens - An Invitro Study. Journal Of Clinical And Diagnostic Research. doi:10.7860/jcdr/2016/22213.8524

Tektook, N.(2018). The Antibacterial effect of extracts of Salvadora Perscia against oral pathogenic bacteria isolated from dental caries. Al-Kufa University Journal for Biology,8(3), 253-263.

Zia-Ul-Haq, M., Ćavar, S., Qayum, M., Imran, I., \& Feo, V. D. (2011). Compositional Studies: Antioxidant and Antidiabetic Activities of Capparis decidua (Forsk.) Edgew. International Journal of Molecular Sciences, 12(12), 8846-8861. doi:10.3390/ijms12128846 